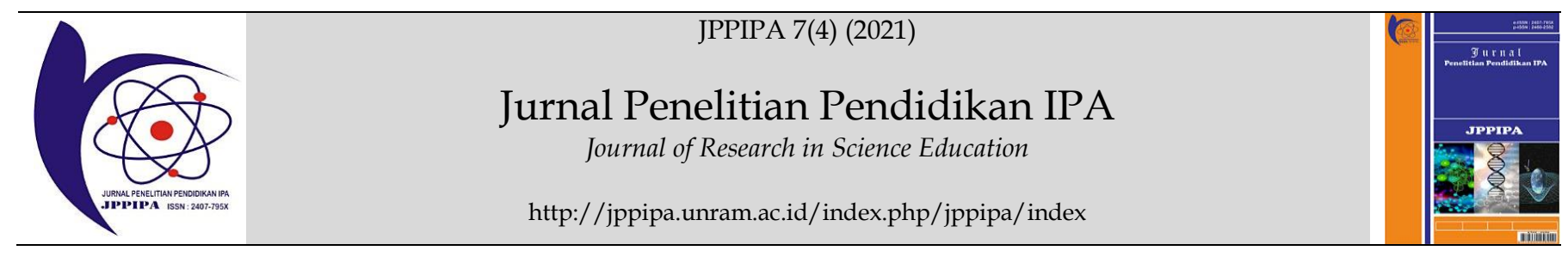

\title{
Implementation of Guided Inquiry Strategy Combined with Scientific Student Worksheets on the Structure and Function of Plant Tissues to Improve Learning Outcomes
}

\author{
Siti Zuhra ${ }^{1}$, Muhibbuddin' ${ }^{1}$, Hafnati Rahmatan ${ }^{*}$ \\ ${ }^{1}$ Biology Education Study Program Postgraduate Program, Syiah Kuala University, Banda Aceh, Indonesia
}

DOI: $10.29303 /$ jppipa.v7i4.766

\section{Article Info}

Received: May 30th, 2021

Revised: September 13th, 2021

Accepted: October $4^{\text {th }}, 2021$

\begin{abstract}
This study aims to determine the application of a guided inquiry strategy combined with scientific student worksheets to improve student learning. The research method used is True experimental using pretest-posttest control group design. The population in this study were students of class XI MIPA MA Negeri 1 Pidie. The number of samples consisted of 132 people, and each class consisted of 33 students. The research instrument used is test questions. The data analysis technique of learning outcomes is through the $\mathrm{N}$-Gain test and the independent sample $\mathrm{t}$-test. The $\mathrm{N}$-gain test of learning outcomes obtained that the average of the experimental class was higher than the control class, where each class was classified as a medium improvement criterion. The independent sample t-test showed a significant average difference between the learning outcomes of the experimental class and the control class, namely $t_{\text {count }}>t_{\text {table }}(65.8>1.65)$. The percentage of $\mathrm{N}-$ Gain learning outcomes in the experimental class is $77.73 \%$ in the high category. This study concludes that there is an increase in student learning outcomes on the material structure and function of plant tissue at MAN 1 Pidie in the experimental class by applying the guided inquiry strategy combined with scientific Student Worksheets.
\end{abstract}

Keywords: Guided inquiry; student worksheets; scientific; learning outcomes.

Citation: Zuhra, S., Muhibbuddin, M., \& Rahmatan, H. (2021). Implementation of Guided Inquiry Strategy Combined with Scientific Student Worksheets on the Structure and Function of Plant Tissues to Improve Learning Outcomes. Jurnal Penelitian Pendidikan IPA, 7(4), 582-586. doi:https://doi.org/10.29303/ippipa.v7i4.766

\section{Introduction}

Biology learning is a visual subject requiring multisensory involvement to understand a sequence of events or a complex mechanism. One of the objectives of learning biology is for students to understand biological concepts and their interrelationships. In achieving this learning, it is necessary to understand the basic concepts of subjects well (Setyowati et al., 2015). Appropriate learning strategies or teaching materials can influence understanding students' conceptions during the learning process.

Based on the results of interviews, students have difficulty in relating the material studied to phenomena that occur in everyday life, especially on the material structure and function of plant tissues. Based on the results of the 2019/2020 odd semester exams, questions related to the material have decreased in value, so that remedial measures must be taken to achieve optimal scores.

So far, the learning process in schools, especially on this material, uses the lecture and discussion method. Learning is still focused on using blackboards and textbooks so that students find it difficult to analyze existing information and are not guided to gain understanding independently. Some students still did not pay attention to the teacher's explanation during the learning process, slept in class, and were less active. 
Some students choose to be silent when invited to interact by asking questions, then when the teacher allows students to ask questions about material that they do not understand, only two or three students ask questions. This causes low learning outcomes for students. This is an essential basis for using concept maps for students in the learning process. Therefore, students should be taught how to use concept maps to make it easier to understand and remember the entire material being studied so that student learning outcomes become more optimal.

Student learning outcomes can be improved by using concept maps in conveying a material so that students feel interested in learning and understanding the material structure and function of plant tissues. Students also do not feel bored during teaching and learning activities, so basic competence 3.3 is to analyze the relationship between cell structure in plant tissues and organ function in plants, which will be achieved using a concept map. The concept map functions as a tool to investigate what students already know, and an evaluation tool can be used to measure learning outcomes (Maurisa and Abdullah, 2016).

Based on the learning outcomes of these students, it is necessary to take action to become better, one of which is by using learning strategies combined with student worksheets. With the student worksheets, it is expected that the learning process can create the effect of the teaching and learning process so that teaching goals can be measured by achieving learning outcomes and helping students build their own understanding.

A good teacher's understanding of the importance of choosing the right strategy in the learning process in the classroom is expected to contribute to improving student learning outcomes. Efforts made by teachers to improve student learning outcomes can be made by applying learning strategies combined with Student Worksheets. One strategy that can empower students' learning outcomes is the guided inquiry learning strategy. Wang \& Posey (2011) stated that the guided inquiry strategy could actively involve students and allow them to learn independently, which will provide more opportunities for students to gain a better understanding of concepts.

Guided inquiry learning strategies combined with scientific Student Worksheets are effective in making students more thorough in carrying out activities and providing experiences and lessons related to daily activities (Rahmadani et al., 2012). Scientific Student Worksheets are effective in improving learning outcomes (Marjan, 2014). According to Permendikbud (2013), in the scientific approach, students will carry out five main activities in learning, namely observing, asking questions, gathering information, associating, and communicating.

The advantage of the scientific Student Worksheet strategy developed in this study is that it is designed in such a way with color images to attract students to read and study it. In addition, the scientific Student Worksheet contains questions or activity steps based on five scientific approaches. The images presented in the Scientific Student Worksheet also relate the material concepts to real-life conditions that have practical value. According to Nurjannah and Dwi (2019), the use of teaching materials in the learning process packaged in a creative, innovative, and interesting way can be used to achieve learning objectives.

The results of several previous studies show the effect of applying guided inquiry learning strategies combined with scientific Student Worksheets in the effective learning process used in increasing students' conceptual understanding, making students more active, and helping improve memory so that they can develop critical thinking skills and improve learning outcomes. (Nisa et al., 2018).

Based on the background of the problem, the purpose of this study was to find out that the application of guided inquiry learning strategies combined with scientific Student Worksheets could improve student learning outcomes on the material of plant tissue structure and function.

\section{Method}

The method used in this study is a true experiment using a quantitative approach (Creswell \& Creswell, 2018). The research design used the PretestPosttest Control Group Design. The experimental class and the control class were selected by randomization. Both groups did the pretest and posttest. Only the experimental group was treated (Cresswell \& Creswell, 2018).

Table 1. Research Design

\begin{tabular}{llccc}
\hline Group & Sample & Pretest & Treatment & Posttest \\
\hline $\begin{array}{l}\text { Experiment } \\
\text { control }\end{array}$ & Random & $\mathrm{O}_{1}$ & $\mathrm{X}$ & $\mathrm{O}_{2}$ \\
\hline Control & $\mathrm{O}_{1}$ & & $\mathrm{O}_{2}$ \\
\hline
\end{tabular}

(Creswell \& Creswell, 2018).

This research was carried out at MAN 1 Pidie for students of class XI science which is located in Komplek Pelajar, Jln. Medan - Banda Aceh, Tijue, Pidie District, Pidie District. The total population consists of all students of class XI.IPAMAN 1 Pidie. The research sample was class XI-IPA3, XI-IPA4, XI-IPA5, and class XI.IPA6, each of which consisted of 33 students. The experimental class was given learning material on the structure and function of plant tissue using a guided 
inquiry strategy combined with scientific Student Worksheets. The control class used conventional learning, which only used textbooks.

The data collection technique in this study was carried out by means of the test method and the assessment of the concept map contained in the Student Worksheet. The research instrument consisted of multiple-choice questions to see student learning outcomes. Learning tools such as syllabus and lesson plans, research instruments used have gone through a logical validation stage by experts.

The results of the respondents' answers were then analyzed to determine the validity, reliability, difficulty index, discriminating power, and distractor function. After that, valid, reliable, discriminative questions were accepted, index difficulty was moderate to difficult, distractors functioned well and then taken to be given during pretest and posttest to see student learning outcomes on the material structure and function of plant tissue.

Data analysis techniques to determine the increase in student learning outcomes by using the $\mathrm{N}$ Gain test. Analysis of the N-Gain test data using the Gain index formula and criteria (Meltzer, 2002). Next, a hypothesis test was conducted to see whether there was a significant difference between the experimental class and the control class, starting with normality, homogeneity, and hypothesis testing using the t-test (independent sample t-test).

\section{Result and Discussion}

The data recapitulation of the average score of pretest, posttest, and N-Gain learning outcomes for students in the control class and the experimental class as a whole is presented in Figure 1 below.

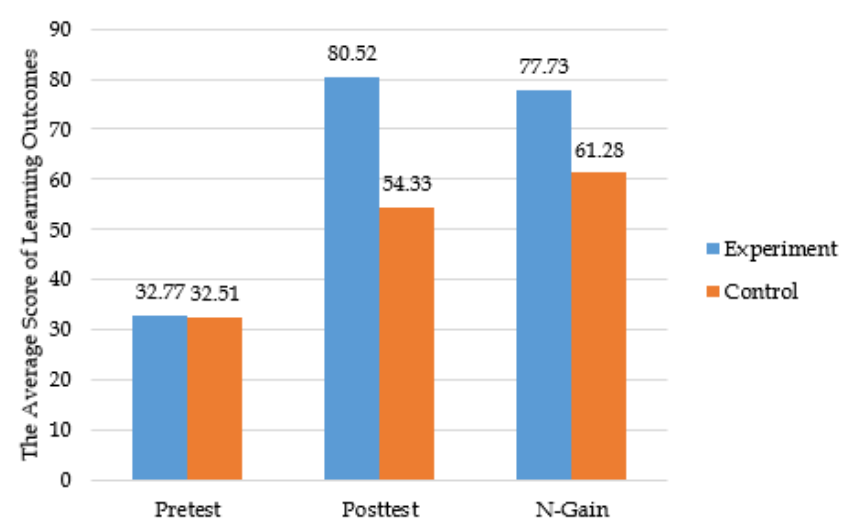

Figure 1. Comparison of the average learning outcomes of the experimental class and the control class

The results of the test of the mean difference between the pretest scores of the experimental class and the control class (Figure 1) showed no significant difference. This shows that students' initial ability in mastering the structure and function of plant tissue at MAN 1 Pidie is the same between the experimental and control classes. After receiving treatment with the application of the Guided Inquiry learning strategy combined with Scientific Student Worksheets (experimental class) and conventional strategies (control class), the mastery of the material increased compared to the initial ability (pretest). This is indicated by the results of the difference in the mean score of the pretest and N-Gain between the experimental and control classes, which are significantly different (Table 2 ).

Table 2. Recapitulation of Different Tests on Average Pretest and N-Gain Learning Outcomes of Students in Experiment Class and Control Class at MAN 1 Pidie

\begin{tabular}{llllll}
\hline No & & \multicolumn{2}{l}{ Experiment Class } & \multicolumn{2}{l}{ Control Class } \\
\cline { 3 - 6 } & & Pretest & N-Gain & Pretest & N-Gain \\
\hline 1 & $\begin{array}{l}\text { Learning } \\
\text { Outcome }\end{array}$ & 32.77 & 77.73 & 32.51 & 61.28 \\
2 & $\begin{array}{l}\text { Normality } \\
3\end{array}$ & 5.91 & 7.66 & 6.69 & 8.08 \\
& T Test & $\begin{array}{l}\mathrm{t}_{\text {count }}<\mathrm{t}_{\text {table }} \\
(1.36<1.65)\end{array}$ & & $\begin{array}{l}\text { t } \mathrm{t}_{\text {count }}>\mathrm{t}_{\text {table }} \\
(65.8>1.65)\end{array}$ \\
\hline
\end{tabular}

There is a difference in N-Gain scores between the experimental class and the control class, which means that the increase in student learning outcomes on the material structure and function of plant tissue at MAN 1 Pidie in the experimental class is better than the control class. The material on the structure and function of plant tissue is considered difficult for students to understand because the material is abstract, and the many structures of plant organs are contained in the material. Therefore, the Guided Inquiry strategy combined with scientific Student Worksheets is effectively used to improve student learning outcomes so that learning is more meaningful.

With the application of Guided Inquiry learning strategies combined with Scientific Student Worksheets, students are given the opportunity to understand the concept of the material better to be achieved by gaining their own experience and knowledge, exercising their intellectual abilities, and stimulating curiosity for the knowledge they have acquired. Students can learn from the activity of working on scientific Student Worksheets so that they can master the concepts that have been taught (Astuti \& Setiawan, 2013).

Student Worksheets can assist teachers in facilitating students in increasing reading, thinking, and assisting in understanding concepts. This is in accordance with the results of research (Mulyana, 2018; Febriyani et al., 2018; Jack, 2013; Zammiluni, 2018), which shows that learning using the Guided Inquiry 
strategy makes a positive contribution to learning outcomes because in the learning process students are required to focus on a large amount of the Student Worksheet that must be completed in groups so that the Guided Inquiry Strategy combined with the Scientific Student Worksheet is not just solving problems, but through the Student, Worksheet students can understand concepts that have been abstract so far become real so that concepts it can be effective and last a long time in his memory.

Several factors that affect the learning process can run well, such as the condition of students who are conducive to learning, the readiness of the teacher and the teaching materials used, and the environment around the class (Helen, 2013). Therefore, the application of the Guided Inquiry learning strategy combined with scientific Student Worksheets on the structure and function of plant tissue can improve the ability of students to achieve the expected goals and obtain maximum learning outcomes. This is different from the learning outcomes obtained by students in the control class.

In the learning process in the control class using conventional learning strategies, students participate less during the learning activities. Only some students are active and involved in giving opinions and asking questions. Thus, student learning outcomes are less than optimal.

\section{Conclusion}

Based on the research and data analysis results, it can be concluded that there is an effect of applying Guided Inquiry learning strategies combined with Scientific Student Worksheets to improve student learning outcomes on the material structure and function of plant tissues.

\section{Acknowledgments}

Acknowledgments are addressed to all parties, namely validators, teachers as facilitators, and others who have contributed to this research. Furthermore, the students of class XI IPA MAN 1 Pidie have collaborated to become objects in this study.

\section{References}

Astuti \& Setiawan. (2013). Pengembangan Lembar Kerja Siswa (LKS) Berbasis Pendekatan Inkuiri Terbimbing Dalam Pembelajaran Kooperatif Pada Materi Kalor. Jurnal Pendidikan IPA Indonesia. 2(1): 89-92. doi: https://doi.org/10.15294/jpii.v2i1.2515

[Indonesian]

Creswell, J.W. \& Creswell, J.D. (2018). Research Design :Qualitative, Quantitative, and Mixed Methods Approaches Fifth Edition. United States of America: Sage Publications.

Febriyani, S.A., Murni, S., Wayan, S. (2018). Pengaruh Model Inquiry Terbimbing dipadu Think Pare Share (TPS) Terhadap Keteramilan Proses dan Hasil Belajar Kognitif Siswa Kelas X SMAN 1 Kepajen. Jurnal Pendidikan Biologi, 9(1): 10-16. doi: http://dx.doi.org/10.17977/um052v9i1p10-16 [Indonesian]

Helen, I. (2013). Effects of guided-inquiry and expository teaching methods on secondary school students' performances in Biology in Imo State. Journal of Educational Research and behavioral Sciences. 2(4):051-057.

Jack, G. U. (2013). Concept Mapping and Guided Inquiry as Effective Techniques for Teaching Difficult Concepts in Chemistry: Effect on Students' Academic Achievement. Journal of Education and Practice, 4(5):9-15. Retrieved from: https://www.iiste.org/Journals/index.php/JEP article/view/4782

Marjan, J. (2014). Pengaruh Pembelajaran Pendekatan Saintifik Terhadap Hasil Belajar Biologi dan Keterampilan Proses Sains Siswa MA Mu'allimat NW Pancoran Selong Kabupaten Lombok Timur Nusa Tenggara Barat. Jurnal Pascasarjana universitas Pendidikan Ganesha, 4(2). Retrieved from: $\quad$ https://ejournalpasca.undiksha.ac.id/index.php/jurnal_ipa/arti cle/view/1316 [Indonesian]

Maurisa, A.M \& Abdullah, H. (2016). Hubungan Kemampuan Membuat Peta Konsep dengan Hasil Belajar Siswa di Kelas XI Pada Materi Pokok Sistem Ekskresi Manusia. Jurnal Pelita Pendidikan, 4(2): 15-19. doi: https://doi.org/10.24114/ipp.v4i2.4017 [Indonesian]

Meltzer, D. E. (2002). The relationship between mathematics preparation and conceptual learning gains in physics: A possible "hidden variable" in diagnostic pretest scores. American Journal of Physics, 70(12), 1259-1268. https://doi.org/10.1119/1.1514215.

Mulyana, S., Rusdi \& Diana, V. (2018). The Effect Of Guided Inquiry Learning Model And Scientific Performance On Student Learning Outcomes. Indonesian Journal Of Science and Education, 2(1): 105-109.

doi: http://dx.doi.org/10.31002/ijose.v2i1.596

Nisa, E. K., Jatmiko, B. \& Koestiari, T. (2018). Development of Guided Inquiry-Based Teaching 
Materials to Increase Critical Thinking Skills Of Highschool Students. Jurnal Pendidikan Fisika Indonesia, 14(1): 18-25. doi: https://doi.org/10.15294/jpfi.v14i1.9549

Nurjannah, \& Dwi, D. F. (2019). The Implementation of Pocket Book as Development of Learning Media to Improve Students ' Motivation. Middle-East Journal of Scientific Research, 27(6), 508-510. https://doi.org/10.5829/idosi.mejsr.2019.508.51 $\underline{0}$.

Permendikbud. (2013). Pendekatan Scientific (ilmiah) dalam Pembelajaran. Jakarta: Pusbangprodik. [Indonesian]

Rahmadani, A., Amalita, N., \& Helma. (2012). Penggunaan Lembar Kerja Siswa Yang dilengkapi Mind Map Dalam Pembelajaran MTK. Jurnal Pendidikan MTK, 1(1):30-34. [Indonesian]

Setyowati, B.E., Widiyatmoko, A., \& Sarwi. (2015). Efektivitas model pembelajaran jigsaw II berbantuan LKS untuk meningkatkan pemahaman konsep dan karakter siswa. Unnes Science Education Journal, 4(3):982-989. doi 10.15294/usej.v4i3.8844 [Indonesian]

Wang, H. \& Posey, L. (2011). An Inquiry-Based Linear algebra Class. Us-China education Review, 4, 489494.

Zammiluni, Z., Ulianas, A., \& Mawardi, M. (2018). Development of Guided Inquiry Based Work Sheet with Class and Laboratory Activity on Chemical Bonding Topic in Senior High School. International Journal of Chemistry Education Research, 2(2), 60-66. doi: https://doi.org/10.20885/ijcer.vol2.iss2.art1 